\title{
Biotinylation enhances the anticancer effects of 15d-PGJ2 against breast cancer cells
}

\author{
CHRISTELLE COLIN $^{1}$, MAXIME MEYER ${ }^{2}$, CLAUDIA CERELLA ${ }^{3}$, ALEXANDRA KLEINCLAUSS $^{1}$, \\ GÉRALD MONARD $^{4}$, MICHEL BOISBRUN $^{2}$, MARC DIEDERICH $^{5}$, STÉPHANE FLAMENT $^{1}$, \\ ISABELLE GRILLIER-VUISSOZ ${ }^{1}$ and SANDRA KUNTZ ${ }^{1}$
}

\author{
${ }^{1}$ Université de Lorraine, CNRS, CRAN, F-54000 Nancy, France; ${ }^{2}$ Université de Lorraine, CNRS, L2CM, F-54000 Nancy, \\ France; ${ }^{3}$ Laboratory for Molecular and Cellular Biology of Cancer, Kirchberg Hospital, L-2540 Luxembourg, \\ Luxembourg; ${ }^{4}$ Université de Lorraine, CNRS, LPCT, F-54000 Nancy, France; ${ }^{5}$ Department of Pharmacy, \\ College of Pharmacy, Seoul National University, Seoul 151-742, Republic of Korea
}

Received October 27, 2017; Accepted March 8, 2018

DOI: $10.3892 /$ ijo.2018.4338

\begin{abstract}
Deoxy- $\Delta^{12,14}$-prostaglandin J2 (15d-PGJ2) is a natural agonist of peroxisome proliferator-activated receptor $\gamma$ (PPAR $\gamma$ ) that displays anticancer activity. Various studies have indicated that the effects of $15 \mathrm{~d}-\mathrm{PGJ} 2$ are due to both PPAR $\gamma$ dependent and -independent mechanisms. In the present study, we examined the effects of a biotinylated form of $15 \mathrm{~d}-\mathrm{PGJ} 2$ (b-15d-PGJ2) on hormone-dependent MCF-7 and triple-negative MDA-MB-231 breast cancer cell lines. b-15d-PGJ2 inhibited cell proliferation more efficiently than $15 \mathrm{~d}-\mathrm{PGJ} 2$ or the synthetic PPAR $\gamma$ agonist, efatutazone. b-15d-PGJ2 was also more potent than its non-biotinylated counterpart in inducing apoptosis. We then analyzed the mechanisms underlying this improved efficiency. It was found not to be the result of biotin receptor-mediated increased incorporation, since free biotin in the culture medium did not decrease the anti-proliferative activity of b-15d-PGJ2 in competition assays. Of note, b-15d-PGJ2 displayed an improved PPAR $\gamma$ agonist activity, as measured by transactivation experiments. Molecular docking analyses revealed a similar insertion of b-15d-PGJ2 and 15d-PGJ2 into the ligand binding domain of PPAR $\gamma$ via a covalent bond with Cys285. Finally, PPAR $\gamma$
\end{abstract}

Correspondence to: Dr Isabelle Grillier-Vuissoz, CRAN, UMR 7039, Faculté des Sciences et Technologies, BP 70239, 54506 Vandœuvre-lès-Nancy Cedex, France

E-mail: isabelle.grillier-vuissoz@univ-lorraine.fr

Abbreviations: DMSO, dimethylsulfoxide; EtOH, ethanol; FCS, fetal calf serum; LBD, ligand binding domain; PDB, protein data bank; PG, prostaglandin; 15d-PGJ2, 15-deoxy- $\Delta^{12,14}$-prostaglandin $\mathrm{J} 2$; b-15d-PGJ2, biotin-conjugated 15 -deoxy- $\Delta^{12,14}$-prostaglandin $\mathrm{J} 2$; PPAR $\gamma$, peroxisome proliferator-activated receptor $\gamma$; PPRE, PPAR response element; TGZ, troglitazone

Key words: breast cancer, peroxisome proliferator-activated receptor $\gamma$, peroxisome proliferator-activated receptor $\gamma$-independent, 15-deoxy- $\Delta 12,14$-prostaglandin $\mathrm{J} 2$, biotin, apoptosis silencing markedly decreased the cleavage of the apoptotic markers, poly(ADP-ribose) polymerase 1 (PARP-1) and caspase-7, that usually occurs following b-15d-PGJ2 treatment. Taken together, our data indicate that biotinylation enhances the anti-proliferative and pro-apoptotic activity of 15d-PGJ2, and that this effect is partly mediated via a PPAR $\gamma$-dependent pathway. These results may aid in the development of novel therapeutic strategies for breast cancer treatment.

\section{Introduction}

Breast cancer is the most prevalent type of cancer affecting women worldwide and represents the leading cause of cancerrelated mortality after lung cancer (1). Three biomarkers are used in clinical practice for tumor characterization and treatment: estrogen receptor $\alpha$, progesterone receptor and epidermal growth factor receptor 2 . Nevertheless, the benefits of therapies targeting these mechanisms are often limited due to resistance. Indeed, approximately one-third of patients with early-stage breast cancer will develop resistance against tamoxifen over a 5-year treatment period, and the majority of patients will become resistant against trastuzumab over a 1-year period $(2,3)$. Moreover, no targeted therapies exist for the aggressive triple-negative tumors, which express none of these three markers. On the whole, epidemiological data reveal the urgent need for novel therapeutic options.

Prostaglandins (PGs) are a family of biologically active endogenous metabolites of arachidonic acid. 15-Deoxy- $\mathrm{D}^{12,14}$ prostaglandin J2 (15d-PGJ2) is a dehydrated derivative of PGD2, that displays potent anticancer properties (4-11). 15d-PGJ2 is a potent natural agonist of peroxisome proliferator-activated receptor gamma (PPAR $\gamma)(12,13)$. PPAR $\gamma$ belongs to a nuclear receptor family that acts as ligand-activated transcription factor. The activation of PPAR $\gamma$ requires ligand binding, heterodimerization with retinoid $\mathrm{X}$ receptor and interaction with the PPAR response element (PPRE) and co-activator recruitment (14-16). Nevertheless, an increasing number of studies have demonstrated that the antitumor effects of 15d-PGJ2 may also be mediated through PPAR $\gamma$-independent pathways (17-24). In vivo, these effects have been confirmed 
in several mouse tumor models (25-27). In breast cancer cell lines, the anti-proliferative effects of $15 \mathrm{~d}-\mathrm{PGJ} 2$ remain modest compared to several synthetic PPAR $\gamma$ ligands (20). Recent clinical trials relaunched PPAR $\gamma$ agonist perspectives for the treatment of cancer. Indeed, pioglitazone in combination with imatinib can erode the cancer stem cell pool and efatutazone alone or in combination with folfiri has been shown to provide some degree of control for metastatic cancer (28-30).

In order to adapt $15 \mathrm{~d}-\mathrm{PGJ} 2$ for clinical use, more potent derivatives are required. Several studies have demonstrated that biotin-conjugated compounds are able to increase the uptake of anticancer drugs in tumor cells (31-34). Previously, we demonstrated that two biotinylated derivatives of $\Delta 2$-troglitazone, PPAR $\gamma$-inactive analogues of troglitazone (TGZ), were more potent than the original compound in inhibiting cell proliferation $(35,36)$.

In the present study, we examined the anti-proliferative activity of a biotin-conjugated 15d-PGJ2 (b-15d-PGJ2) on estrogen-dependent MCF-7 and triple-negative MDA-MB-231 breast cancer cells. We demonstrate that b-15d-PGJ2 is more efficient than 15d-PGJ2 in inhibiting cell proliferation and inducing apoptosis. Molecular docking analysis indicated that b-15d-PGJ2 was able to bind the ligand-binding domain of PPAR $\gamma$, in a similar manner as 15d-PGJ2. This compound also displayed an improved PPAR $\gamma$ agonist activity, as measured by transactivation experiments. RNA interference experiments revealed that a PPAR $\gamma$-dependent pathway was involved in b-15d-PGJ2-induced apoptosis. This study provides a better understanding of the anti-proliferative effects of PPAR $\gamma$ ligands and supports the conception of more efficient derivatives, which may be used for the development of novel therapeutic strategies for breast cancer.

\section{Materials and methods}

Reagents and cell lines. 15d-PGJ2 and 15-deoxy- $\Delta^{12,14}$ prostaglandin J2-biotinamide (b-15d-PGJ2) were purchased respectively, from Merk-Millipore (Fontenay-sous-Bois, France) and Cayman Chemical Co. (Ann Arbor, MI, USA). Efatutazone(RS5444; CS-7017)was obtained from ChemScene, (Monmouth Junction, NJ, USA). The small-interfering RNA (siRNA) duplexes targeting PPAR $\gamma$ and non-specific control siRNA were purchased from Eurogentec (Angers, France) and PCR primers from Euromedex (Souffelweyersheim, France).

The human breast cancer cell lines, MCF-7 and MDA-MB-231, were purchased from the American Type Culture Collection (ATCC, Manassas, VA, USA). Dulbecco's modified Eagle's medium (DMEM), Leibovitz's L-15 medium, trypsin-EDTA and PBS were purchased from Life Technologies (Saint Aubin, France). Biotin, ethanol (EtOH), dimethylsulfoxide (DMSO), fetal calf serum (FCS), L-glutamine and all other chemicals were purchased from Sigma-Aldrich (Lyon, France).

Cell culture and treatment. The MCF-7 and MDA-MB-231 cells were cultured at $37^{\circ} \mathrm{C}$ under $5 \% \mathrm{CO}_{2}$ in DMEM or without $\mathrm{CO}_{2}$ in L-15 medium, respectively. Both media were supplemented with $10 \%$ fetal calf serum FCS and $2 \mathrm{mM} \mathrm{L-glutamine.} \mathrm{The} \mathrm{cells}$ were treated with $0.1 \% \mathrm{EtOH}$ (vehicle) or various concentrations of 15d-PGJ2, b-15d-PGJ2 and efatutazone in 1\% FCS-containing medium. 15d-PGJ2 and efatutazone were dissolved at $50 \mathrm{mM}$ in sterile DMSO. b-15d-PGJ2 was dissolved at $1.6 \mathrm{mM}$ in $\mathrm{EtOH}$. All these compounds were stored frozen at $-20^{\circ} \mathrm{C}$.

Cell proliferation assays. The MCF-7 and MDA-MB-231 cells $\left(0.8 \times 10^{5}\right.$ cells $\left./ \mathrm{ml}\right)$ were seeded in 12 -well plates and treated with various concentrations of 15d-PGJ2, b-15d-PGJ2, efatutazone (2 $\mu \mathrm{M}$ up to $50 \mu \mathrm{M}$ ) and $\mathrm{EtOH}$ (control) for $24 \mathrm{~h}$. For competition experiments, various concentrations of free biotin $(5$ or $25 \mu \mathrm{M})$ were added together with $15 \mathrm{~d}-\mathrm{PGJ} 2$ or b-15d-PGJ2. Each treatment was performed in triplicate. Cell proliferation was measured using CellTiter-Glo ${ }^{\mathrm{TM}}$ Luminescent Cell Viability assay (Promega, Charbonnières, France).

For the different compounds, the concentration leading to a decrease of $50 \%$ in the number of viable cells $\left(\mathrm{IC}_{50}\right)$ was determined. Efatutazone was used as a gold standard, since it is a PPAR $\gamma$ activator currently evaluated for clinical trials (37).

Transient transfection assays. The MCF-7 cells $\left(1.6 \times 10^{5}\right.$ cells $\left./ \mathrm{ml}\right)$ were seeded in 24-well plates and transfected with pPPRE $\mathrm{E}_{3}$-tk-luc reporter $(1 \mu \mathrm{g} /$ well) and $\mathrm{pCMV}-\beta$-galactosidase $(\beta-\mathrm{Gal})$ $(0.6 \mu \mathrm{g} /$ well $)$, as an internal control plasmid, in the presence of a human PPAR $\gamma$ expression vector $(2 \mu \mathrm{g} /$ well). pPPRE -tk-luc reporter comprises three copies of PPRE from the promoter of the rat ACO gene. hPPAR $\gamma 2$ was cloned into the pcDNA3 vector. $\mathrm{pCMV}-\beta$ is a plasmid encoding $\beta$-galactosidase under the control of the cytomegalovirus promotor. The pPPRE $E_{3}$-tk-luc, the human PPAR $\gamma$ expression vector and the pCMV- $\beta$-galactosidase construct were a gift from Professor P. Becuwe, Dr L. Domenjoud and Professor O. Nusse, respectively. Cell transfection was performed using Exgen 500 (Euromedex) according to the manufacturer's instructions. Following transfection, the cells were allowed to grow for $24 \mathrm{~h}$ in DMEM supplemented with $10 \%$ FCS stripped in dextrancoated charcoal and were treated with $10 \mu \mathrm{M}$ of $15 \mathrm{~d}-\mathrm{PGJ} 2$, b-15d-PGJ2, efatutazone and ethanol as a control for $24 \mathrm{~h}$. Luciferase and $\beta$-Gal activities were measured as previously described (35).

RNA interference. The MCF-7 and MDA-MB-231 cells $\left(2 \times 10^{5}\right.$ cells $\left./ \mathrm{ml}\right)$ were seeded in 6-well culture plates and were transfected with $100 \mathrm{nM}$ of PPAR $\gamma$ siRNA duplex mix or control scRNAs [negative control (OR-0030-neg05)] using Oligofectamine ${ }^{\mathrm{TM}}$ reagent (Life Technologies) according to the manufacturer's instructions. The siRNA sequences against human PPAR $\gamma$ (PPAR $\gamma$-siRNAs) were as follows: 5'-GUA-CCA-AAG-UGC-AAU-CAAATT-3' and 5'-UUUGAU-UGC-ACU-UUG-GUA-CTT-3' for duplex no. 1, 5'-CAA-UCA-GAU-UGA-AGC-UUA-UTT-3' and 5'-AUAAGC-UUC-AAU-CUG-AUU-GTT-3' for duplex no. 2. Twenty hours later, the cells were exposed to $15 \mathrm{~d}-\mathrm{PGJ} 2$ $(10 \mu \mathrm{M})$, b-15d-PGJ2 $(10 \mu \mathrm{M})$ or $0.1 \% \mathrm{EtOH}$ (vehicle control) for $24 \mathrm{~h}$ and harvested for RT-PCR or western blot analyses.

Semi-quantitative RT-PCR. The MCF-7 and MDA-MB-231 cells $\left(2 \times 10^{5}\right.$ cells $\left./ \mathrm{ml}\right)$ were seeded overnight in 6-well plates and were exposed to $15 \mathrm{~d}-\mathrm{PGJ} 2(10 \mu \mathrm{M}), \mathrm{b}-15 \mathrm{~d}-\mathrm{PGJ} 2(10 \mu \mathrm{M})$ or EtOH (0.1\%) for $24 \mathrm{~h}$. RT-PCR was performed as previously described (38). Briefly, cDNA was further amplified by PCR with specific primers: 5'-GACCACT CCCACTCCTTT-3' and 
5'-CGACATTCAATTGCCATGAG-3' for PPAR $\gamma$, 5'-TACA TGGGTGGGGTGTTGAA-3' and 5'-AAGAGAGGCATCCT CACCC-3' for $\beta$-actin. Amplification was carried out under the following conditions: i) initial denaturation $94^{\circ} \mathrm{C}$ for $2 \mathrm{~min}$; ii) $94^{\circ} \mathrm{C}$ for $30 \mathrm{sec}, 58^{\circ} \mathrm{C}$ for $30 \mathrm{sec}$ and $72^{\circ} \mathrm{C}$ for $45 \mathrm{sec}$; iii) $10 \mathrm{~min}$ extension step at $72^{\circ} \mathrm{C}$. Subsequently, $20 \mu \mathrm{l}$ of the PCR products were mixed with loading buffer $(5 \mu \mathrm{l})$ and submitted to electrophoresis in a $1.5 \%$ agarose gel at $90 \mathrm{~V}$ for $35 \mathrm{~min}$ at room temperature. The gel was stained with ethidium bromide, viewed and photographed on a UV-transilluminator (Gel Doc 2000, Bio-Rad Laboratories, Marnes-la-Coquette, France). The intensity of the PPAR $\gamma$ signal was normalised to $\beta$-actin using Gel Doc 2000 and a software package (Quantity One v.4·3·1) (both from Bio-Rad Laboratories).

Western blot analysis. The MCF-7 and MDA-MB-231 cells $\left(2 \times 10^{5}\right.$ cells $\left./ \mathrm{ml}\right)$ were seeded in 6-well plates and were treated as described below for $24 \mathrm{~h}$ and subjected to western blot analysis as previously described (38). The antibodies against cleaved PARP-1 (F21-852, BD Biosciences, Le Pont-de-Claix, France) and caspase-7 (9494, Cell Signaling Technology, Danvers, USA) were diluted at 1:1,000. The monoclonal antibody against tubulin (EP1332Y, Epitomics, Burlingame, CA, USA) and the polyclonal antibody against $\beta$-actin (SC-1615, Santa Cruz Biotechnology, Dallas, TX, USA) were used diluted at 1:2,000. Non-specific binding sites were blocked in TNT buffer (50 mM Tris-HCl, $150 \mathrm{mM} \mathrm{NaCl}, 0.1 \%$ Tween-20) with $5 \%$ non-fat powder milk and the membranes were incubated with the primary antibodies diluted in blocking solution overnight at $4^{\circ} \mathrm{C}$. The membranes were probed with appropriate horseradish peroxidase-conjugated secondary antibodies (SC-2005 for mouse antibody and SC-2004 for rabbit antibody, Santa Cruz Biotechnology) for $1 \mathrm{~h}$ at room temperature. On some western blots, the intensity of the bands corresponding to cleaved PARP-1 and caspase-7 was normalized to $\beta$-actin or tubulin by using Gel Doc 2000 and a software package (Quantity One v.4·3·1) (both from Bio-Rad Laboratories).

Nuclear staining. The MCF-7 and MDA-MB-231 cells $\left(2 \times 10^{5}\right.$ cells $\left./ \mathrm{ml}\right)$ were seeded in 6 -well plates and were treated with $15 \mathrm{~d}-\mathrm{PGJ} 2$ or b-15d-PGJ2 $(10 \mu \mathrm{M})$ for $24 \mathrm{~h}$. Following centrifugation (10 min, 1,200 rpm), the pellet was resuspended in $50 \mu \mathrm{l}$ of media and the nuclei were stained with Hoechst dye (Hoechst 33342; AAT Bioquest, Sunnyvale, CA, USA). Fluorescent staining was observed under an Eclipse 80i microscope (Nikon, Champigny-sur-Marne, France). Images were collected using LuciaG software 4.81 (Laboratory imaging/ Nikon).

Statistical analysis. The results of each experiment are expressed as the mean \pm standard error of the mean (SEM) of 3 to 5 different experiments. Bars represent the means \pm SEM. Statistical differences were tested using analysis of variance (ANOVA) followed by Bonferroni, Student-Newman-Keuls or Student's t-test post hoc comparisons (SPSS v11.0 Computer Software). Differences in which the P-value was $<0.05$ were considered statistically significant.

Molecular docking. Molecular docking of 15d-PGJ2 and b-15d-PGJ2 in the ligand binding domain (LBD) of PPAR $\gamma$ was performed using the Autodock software, version 4.2 (39). The target protein structure corresponds to the Protein Data Bank (PDB) entry 3V9V (40). This structure was preferred over PDB entry 2ZK1 (41), which corresponds to 15d-PGJ2 bound to PPAR $\gamma$ as the former structure has a better resolution $(1.60 \AA$ for $3 \mathrm{~V} 9 \mathrm{~V}$ vs. $2.60 \AA$ for $2 \mathrm{ZK} 1$, respectively) and as its LBD pocket can accommodate larger ligands. Ligands were manually built with the GaussView software (42). After a semiempirical PM6 (43) geometrical optimization with Gaussian 09 (44), atomic charges were computed using the AM1-BCC (45) scheme by the Antechamber program from the AmberTools suite of programs (46). Atomic charges for the protein were assigned according to the Amber ff $12 \mathrm{SB}$ force field (47). A grid of $78 \times 78 \times 78$ points centered on the $\mathrm{C} \alpha$ of Cys285 (Helix3 of the LBD of PPAR $\gamma$ ) was built with a spacing of $0.375 \AA$ using AutoGrid. The number of total docking runs was set to 30 , each with a population of 150 individuals, a maximum number of generations set at 27,000 and a maximum number of energy evaluations set at 108 . All other parameters were given default values.

\section{Results}

b-15d-PGJ2 markedly decreases cell viability compared to the PPAR $\gamma$ agonists, $15 d-P G J 2$ and efatutazone. The antiproliferative effects of $15 \mathrm{~d}-\mathrm{PGJ} 2$, its biotinylated derivative, b-15d-PGJ2, and the PPAR $\gamma$ agonist, efatutazone (Fig. 1A) were measured on hormone-dependent MCF-7 and triplenegative MDA-MB-231 breast cancer cell lines. The cells were exposed to increasing concentrations of each compound or corresponding ethanol concentrations (control cells). Cell viability was determined after $24 \mathrm{~h}$ of treatment (Fig. 1B). b-15d-PGJ2 induced a potent dose-dependent inhibition of MCF-7 $\left(\mathrm{IC}_{50}, 9.8 \pm 1.2 \mu \mathrm{M}\right)$ and MDA-MB-231 ( $\mathrm{IC}_{50}$, $6.0 \pm 0.1 \mu \mathrm{M})$ cell proliferation, compared to $15 \mathrm{~d}-\mathrm{PGJ} 2$ or efatutazone used as a positive control $\left(\mathrm{IC}_{50}\right.$ both $\left.>50 \mu \mathrm{M}\right)$. The anti-proliferative effect of b-15d-PGJ2 differed significantly from that of $15 \mathrm{~d}-\mathrm{PGJ} 2$ and efatutazone, from concentration as low as 15 and $10 \mu \mathrm{M}$ in the MCF-7 and MDA-MB-231 cells, respectively. Of note, the MDA-MB-231 cells were significantly more sensitive than the MCF-7 cells to b-15d-PGJ2 treatment $\left(\mathrm{IC}_{50}, \mathrm{P}=0.016\right)$.

b-15d-PGJ2 is a more potent inducer of apoptosis. First, we investigated the activation of the executioner caspase, caspase-7 (since caspase-3 is not expressed in MCF-7 cells), as well as PARP-1 cleavage, since it is a well-known caspase substrate (Fig. 2A). At the concentration of $10 \mu \mathrm{M}$ b-15d-PGJ2, western blot analysis revealed the cleavage of caspase-7 and the cleavage of PARP-1 after $24 \mathrm{~h}$ of treatment compared with the 15d-PGJ2-treated or the control cells. To ascertain our results, we examined the effects of b-15d-PGJ2 on nuclear morphology in Hoechst-stained cells. Both cell lines were treated for $24 \mathrm{~h}$ with b-15d-PGJ2 $(10 \mu \mathrm{M})$. As depicted in Fig. 2B, the treated cells exhibited characteristics of apoptosis, such as cell shrinkage, nuclear condensation and fragmentation compared to the untreated controls. Taken together, these results provide insight into the induction of apoptosis in both cell lines following treatment with $10 \mu \mathrm{M}$ b-15d-PGJ2. 
A
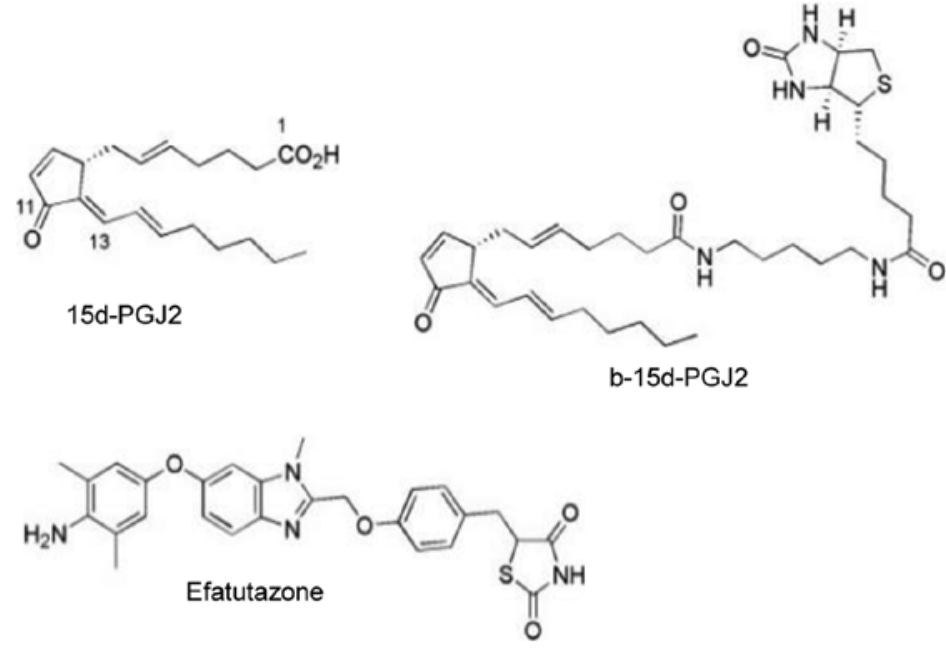

B
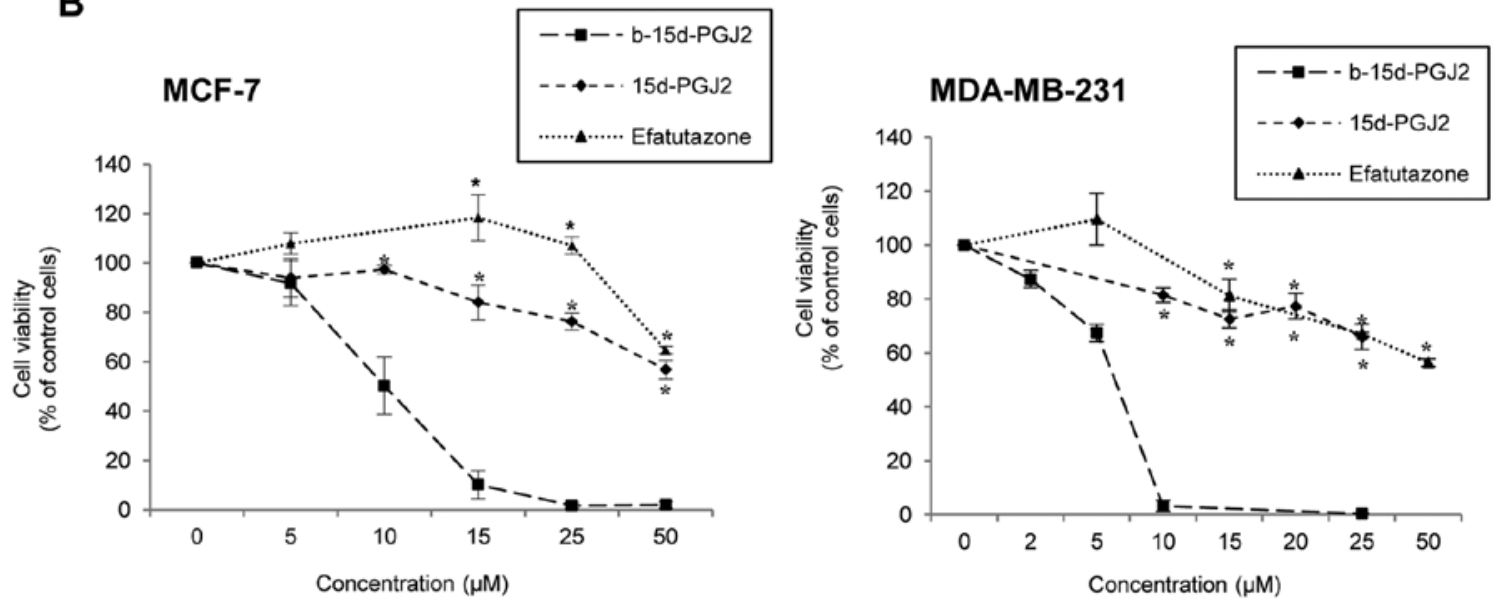

Figure 1.Effects of b-15d-PGJ2 on the viability of MCF-7 and MDA-MB-231 cells. (A) Chemical structure of 15d-PGJ2, b-15d-PGJ2 and efatutazone. (B) MCF-7 and MDA-MB-231 cells were treated for $24 \mathrm{~h}$ with increasing concentrations of 15d-PGJ2, its biotinylated derivative b-15d-PGJ2 or efatutazone. The control cells were treated with ethanol $(0.1 \%)$. Cell numbers were expressed as percentages of the control. Results are presented as the means \pm SEM of 3 or 4 independent experiments (each group, $\mathrm{n}=3-4$ ). ${ }^{*} \mathrm{P}<0.05$, significant difference between the $\mathrm{b}-15 \mathrm{~d}-\mathrm{PGJ} 2$ group compared with the $15 \mathrm{~d}-\mathrm{PGJ} 2$ and efatutazone groups.

A

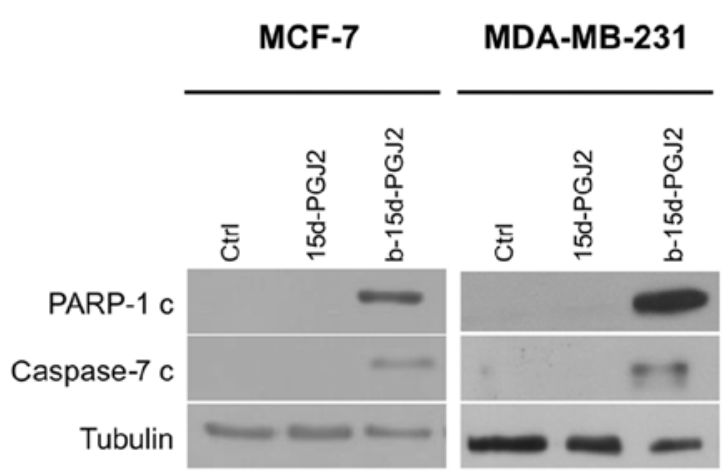

B

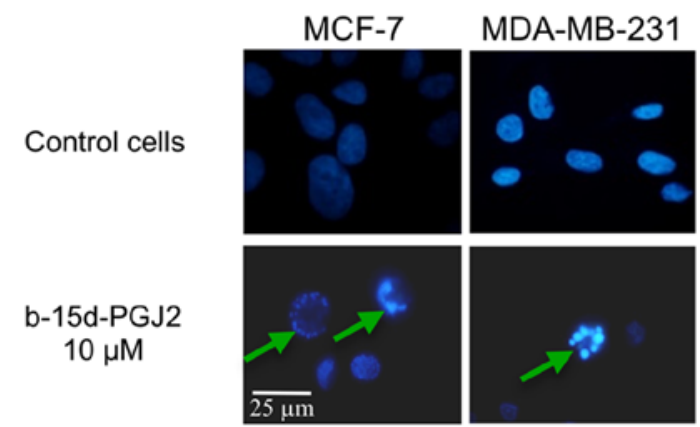

Figure 2. b-15d-PGJ2 triggers PARP-1 and caspase-7 cleavage in the MCF-7 and MDA-MB-231 cells. (A) Cells were exposed to $10 \mu \mathrm{M} 15 \mathrm{~d}-\mathrm{PGJ} 2$ or $10 \mu \mathrm{M}$ b-15d-PGJ2 for $24 \mathrm{~h}$. Control cells (Ctrl) were treated with $0.1 \%$ ethanol. The cells were then were lysed for protein analysis. Following electrophoresis (SDS-PAGE), proteins were transferred onto a nitrocellulose membrane for the analysis of cleaved PARP-1 and cleaved caspase-7. Tubulin was used as a loading control. (B) The MCF-7 and MDA-MB-231 control cells were treated with ethanol $0.1 \%$ (control cells) or treated with b-15d-PGJ2 (10 $\mu \mathrm{M}$ ) and nuclei were stained with Hoechst. Green arrows indicate examples of apoptotic nuclei. Scale bar, $25 \mu \mathrm{M}$.

Biotin group is not responsible for the enhanced antiproliferative effects of $b-15 d-P G J 2$. We then performed competition experiments with free biotin to determine whether the enhanced anti-proliferative effect of b-15d-PGJ2 could be the result of an increased internalization mediated by a biotin membrane receptor (Fig. 3). We examined viability of 
MCF-7

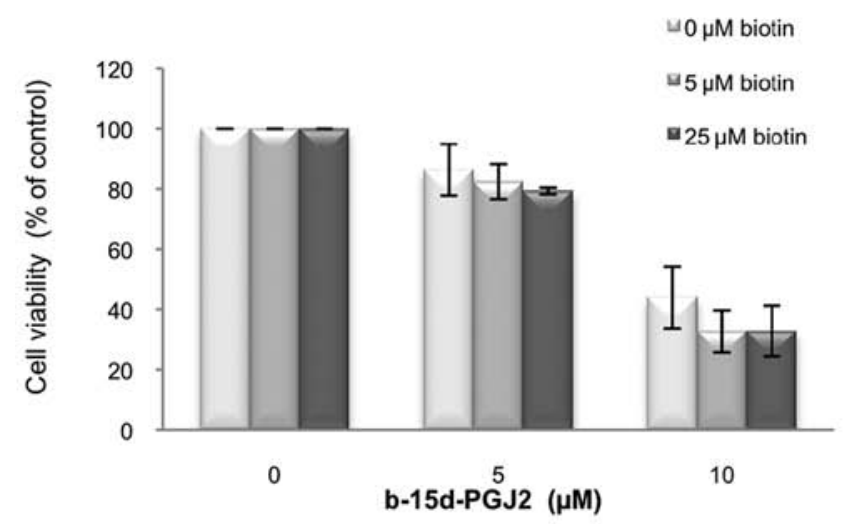

MDA-MB-231

$\checkmark 0 \mu \mathrm{M}$ biotin

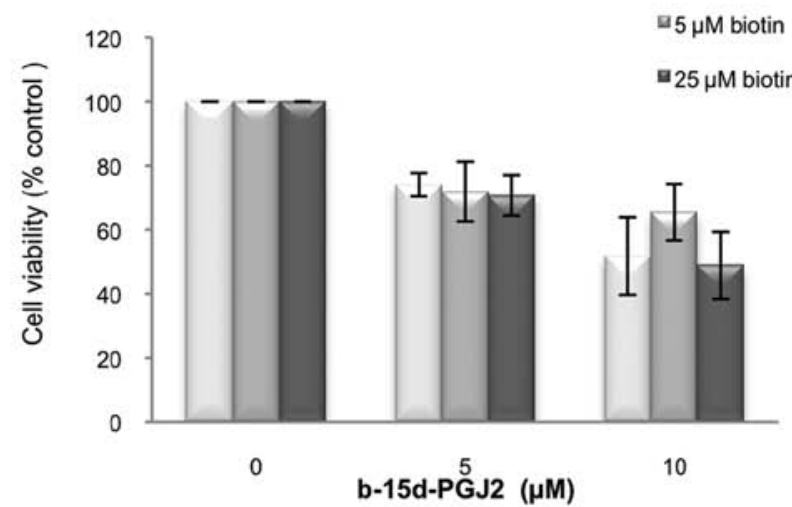

Figure 3. Biotin is not responsible for the enhanced anti-proliferative effect of b-15d-PGJ2. Competition experiments between b-15d-PGJ2 and free biotin were performed in the MCF-7 and MDA-MB-231 cells. Both cell lines were treated with 5 or $10 \mu \mathrm{M}$ of b-15d-PGJ2 in the presence of increasing concentrations

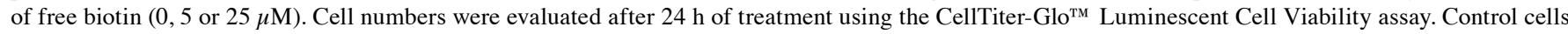
were treated with ethanol $(0.1 \%)$. Cell numbers were expressed as percentages of the control. Results are presented as the means \pm SEM of 3 or 4 independent experiments.

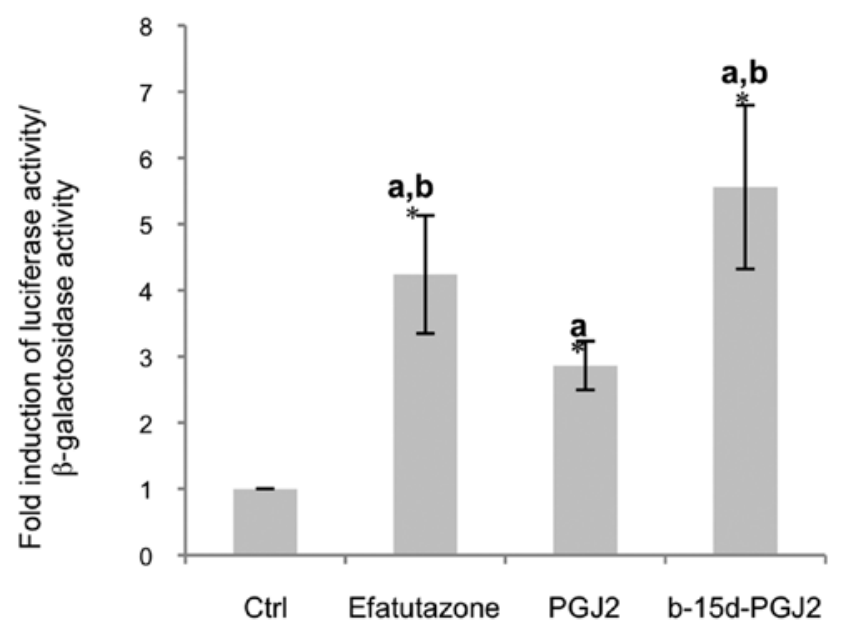

Figure 4. PPAR $\gamma$ transactivation by b-15d-PGJ2 in MCF-7 cells. MCF-7

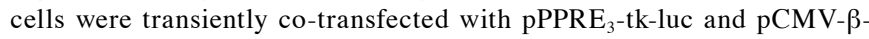
galactosidase in the presence of a human PPAR $\gamma$ expression vector. The cells were treated for $24 \mathrm{~h}$ with $10 \mu \mathrm{M}$ efatutazone, 15d-PGJ2 (PGJ2) and b-15d-PGJ2 (b-15d-PGJ2). Control cells were treated with 0.1\% ethanol (Ctrl). Luciferase reporter activity was measured, normalized to $\beta$-galactosidase activity and expressed as percentage of the control set to $100 \%$. The values represent the means \pm SEM of 3 to 5 different experiments. In each experiment, the activities of transfected plasmids were assayed after duplicate transfections. ${ }^{*} \mathrm{P}<0.05$, significant difference as compared to the untreated controls, as shown by ANOVA followed by the Bonferonni post hoc test ${ }^{a} \mathrm{P}<0.05$, significantly different from the control group; ${ }^{\mathrm{b}} \mathrm{P}<0.05$, significantly different from the 15d-PGJ2 group, as shown by ANOVA followed by Student-Newman-Keuls test.

the MCF-7 and MDA-MB-231 cells following $24 \mathrm{~h}$ of treatment with b-15d-PGJ2 $(0,5$ and $10 \mu \mathrm{M})$ in the presence of increasing concentrations of biotin $(0,5$ and $25 \mu \mathrm{M})$. In both cell lines, free biotin up to $25 \mu \mathrm{M}$ in the culture medium did not significantly modify the effects of b-15d-PGJ 2 on cell viability. This result thus excluded biotin receptors as a cause for the enhanced anti-proliferative effects of b-15d-PGJ2.

b-15d-PGJ2 is a potent PPAR $\gamma$ agonist. In order to examine whether the biotin moiety could affect PPAR $\gamma$ activation, we compared the effects of b-15d-PGJ2 to the PPAR $\gamma$ agonists, efatutazone and 15d-PGJ2. The MCF-7 cells were transiently transfected with a pPPRE $E_{3}$-tk-luc vector in the presence of a human PPAR $\gamma$ expression vector. Following $24 \mathrm{~h}$ of treatment with $10 \mu \mathrm{M}$ efatutazone, 15d-PGJ2 or b-15d-PGJ2, luciferase activity was stimulated 4.2-fold by efatutazone and 5.5 -fold by b-15d-PGJ2, whereas 15d-PGJ2 induced only a 3.2-fold stimulation (Fig. 4). This result clearly indicated that b-15d-PGJ2 is a potent PPAR $\gamma$ agonist.

b-15d-PGJ2 docks into the LBD of PPAR $\gamma$, in a similar manner as 15d-PGJ2. In order to determine the mechanisms through which b-15d-PGJ2 activates PPAR $\gamma$, we performed docking of both ligands into the ligand binding pocket of the receptor. The docking of 15d-PGJ2 in the LBD of PPAR $\gamma$ yielded a pose in the $3 \mathrm{~V} 9 \mathrm{~V}$ structure that was very similar to the X-ray pose (PDB entry code 2ZK1). It is important to note that in the $2 \mathrm{ZK} 1$ entry, a covalent bond between 15d-PGJ2 and Cys285 was present, which cannot be reproduced by Autodock. However, in the best pose, the distance that we obtained between the sulfur atom of Cys285 and C-13 of 15d-PGJ2 (the exocyclic Michael acceptor) remained small and compatible with a subsequent chemical bonding (Fig. 5).

Our docking protocol being able to reproduce in the $3 \mathrm{~V} 9 \mathrm{~V}$ structure a correct pose for 15d-PGJ2, we docked b-15d-PGJ2 into the same target protein using the same protocol. In solution, each of the two amide bonds of b-15d-PGJ2 can adopt configurations $\mathrm{Z}$ or $\mathrm{E}$. Therefore, we considered in our docking study, 4 different types of structures for b-15d-PGJ2 (i.e., ZZ, $\mathrm{ZE}, \mathrm{EZ}$, or EE). Our docking results were very similar for all 4 isomers. In all cases, the biotin moiety lies out of the PPAR $\gamma$ ligand-binding pocket. The only significant interaction of this molecular fragment was the interaction of the first amide bond (i.e., the amide bond linked to the $15 \mathrm{~d}-\mathrm{PGJ} 2$ moiety) and Ser342. Regardless of its configuration, the amide bond formed a hydrogen bond with either the backbone of Ser342 (N-H of Ser342 donates to the $\mathrm{C}=\mathrm{O}$ of the amide bond) and/or the side chain of Ser342 (the amide bond N-H donates to the hydroxyl oxygen of Ser342). The '15d-PGJ2' moiety adopted 

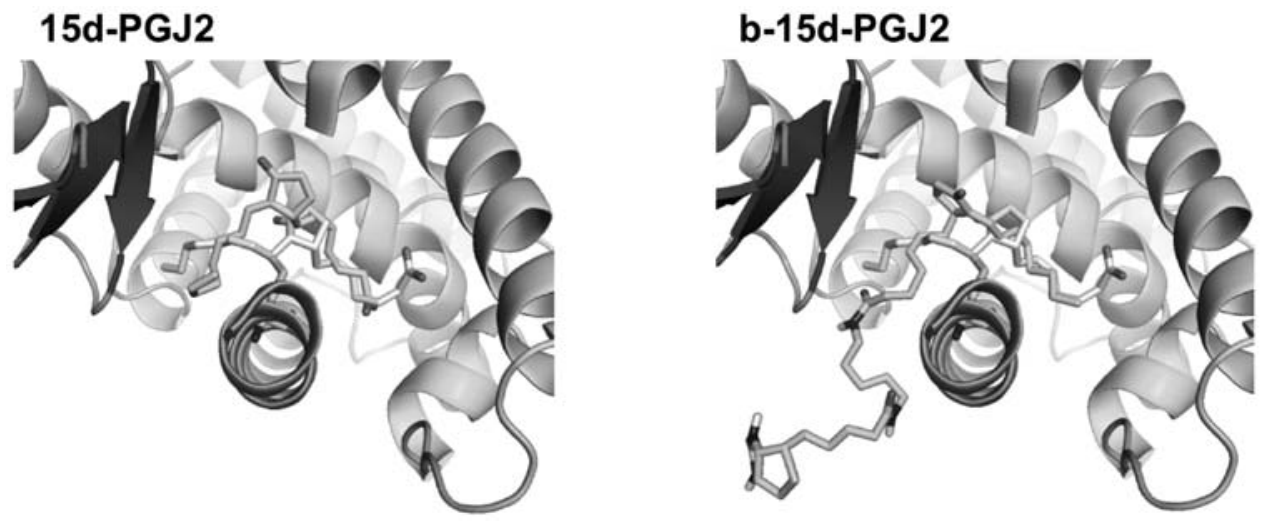

Figure 5. b-15d-PGJ2 binds to the ligand binding domain of PPAR $\gamma$. Best docking pose for 15d-PGJ2 and b-15d-PGJ2 in the LBD of PPAR $\gamma$ : PPAR $\gamma$ is represented in cartoon mode; white sticks represent the covalently bound structure of 15d-PGJ2 (PDB entry 2ZK1); grey sticks represent the docked ligand structures.

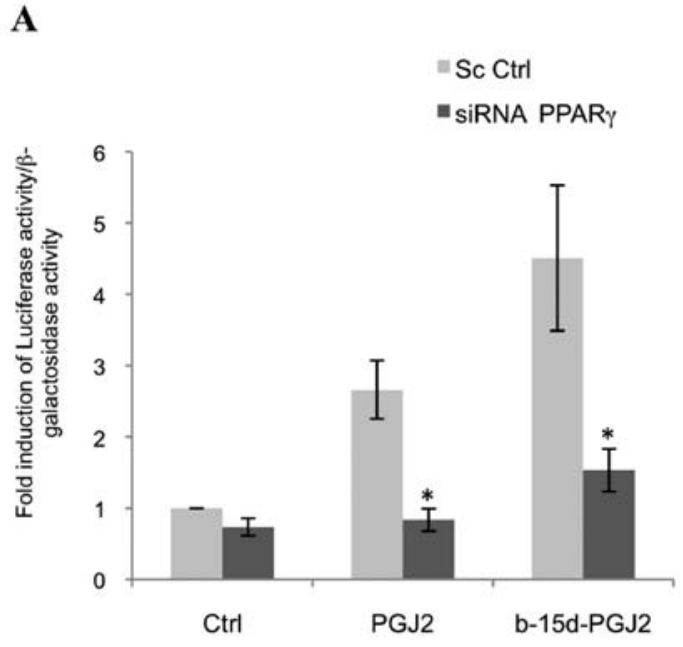

B

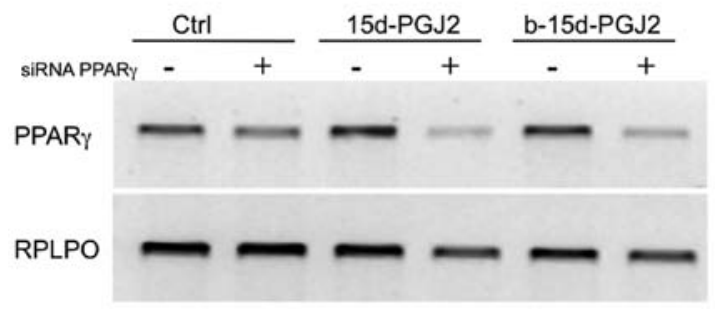

Figure 6. Silencing of PPAR $\gamma$ by RNA interference in MCF-7 cells. (A) MCF-7 cells were transiently co-transfected with pPPRE $\mathrm{E}_{3}$-tk-luc and pCMV- $\beta$-galactosidase with siRNA directed against PPAR $\gamma(\operatorname{siRNAPPAR} \gamma)$ or scrambled siRNA (Sc Ctrl). The cells were treated for $24 \mathrm{~h}$ with $10 \mu \mathrm{M}$ 15d-PGJ2 (PGJ2) and b-15d-PGJ2 (b-15d-PGJ2). Control cells were treated with $0.1 \%$ ethanol (Ctrl). Luciferase reporter activity was measured, normalized with the $\beta$-galactosidase activity and expressed as percentage of the control set to $100 \%$. The values represent the means \pm SEM of 3 different experiments. In each experiment, the activities of transfected plasmids were assayed in duplicate transfections. ${ }^{*} \mathrm{P}<0.05$, significant difference between Sc Ctrl- or siRNA-treated cells for each treatment, as shown by Student's t-test. (B) MCF-7 cells were transiently transfected with double-stranded siRNA targeting PPAR $\gamma(+)$ or Sc Ctrl (-) for $24 \mathrm{~h}$. The cells were then exposed to $10 \mu \mathrm{M}$ of $15 \mathrm{~d}-\mathrm{PGJ} 2$ or b-15d-PGJ2 for $24 \mathrm{~h}$. Control cells (Ctrl) were treated with ethanol $(0.1 \%)$. Total RNA was isolated and $1 \mu \mathrm{g}$ was used for reverse transcription. PCR was carried out using PPAR $\gamma$ specific primers. Human ribosomal protein P0 (RPLP0) corresponds to the amplification of a control housekeeping gene. The PCR products were observed after agarose gel electrophoresis $(1.2 \%)$ and ethidium bromide staining. a similar conformation than the best $15 \mathrm{~d}-\mathrm{PGJ} 2$ docking pose with a closer distance between Cys285 and C-13 of 15d-PGJ2 (3.1 vs. $3.8 \AA$ between the two atoms for the b-15d-PGJ2 pose vs. the $15 \mathrm{~d}-\mathrm{PGJ} 2$ pose, respectively). Taken together, our results indicated that $b-15 d-P G J 2$ activated PPAR $\gamma$ via a covalent bond with Cys 285 in a very similar manner to what has been reported for 15d-PGJ2 (41).

b-15d-PGJ2-induced apoptosis is attenuated with PPAR silencing. To determine whether b-15d-PGJ2-induced apoptosis was mediated by PPAR $\gamma$, we used siRNA directed against this receptor in the MCF-7 cells. First, we verified the silencing of PPAR $\gamma$ by performing a functional assay, in which the MCF-7 cells were co-transfected with the reporter

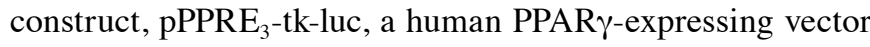
and PPAR $\gamma$ siRNA or a scramble sequence. The cells were then treated with 15d-PGJ2, b-15d-PGJ2 $(10 \mu \mathrm{M}, 24 \mathrm{~h})$ or ethanol as a control. In the presence of PPAR $\gamma$ siRNA, we observed a potent and significant decrease in luciferase activity following treatment with 15d-PGJ2 (3.2-fold) and following treatment with b-15d-PGJ2 (2.9-fold) compared to scramble sequence (Fig. 6A). These data were then confirmed by the analysis of the PPAR $\gamma$ mRNA levels. (Fig. 6B). We then also examined the effect of PPAR $\gamma$ silencing on the b-15d-PGJ2-induced apoptosis of both cell lines. After PPAR $\gamma$ silencing, the pro-apoptotic signals usually induced by b-15d-PGJ2 were significantly reduced in the MCF-7 cells: the level of cleaved PARP-1 and cleaved caspase-7 exhibited a 2- and 3-fold decrease, respectively (Fig. 7A). PPAR $\gamma$ silencing led to a similar trend in the MDA-MB-231 cells, with a decrease of cleaved PARP-1 and caspase-7 of 1.8- and 1.6-fold, respectively; however, no significant difference was observed (Fig. 7B).

\section{Discussion}

De novo or acquired resistance to current therapies constitutes a main obstacle in breast cancer therapy. In this context, the development of alternative treatments remains essential. The PPAR $\gamma$ agonist, 15d-PGJ2, has been broadly studied for its anticancer properties $(4-11,48,49)$. Recently, we described that biotinylation enhanced the anti-proliferative activity of TGZ, a synthetic agonist of PPAR $\gamma$, in breast cancer cells (36). 
A

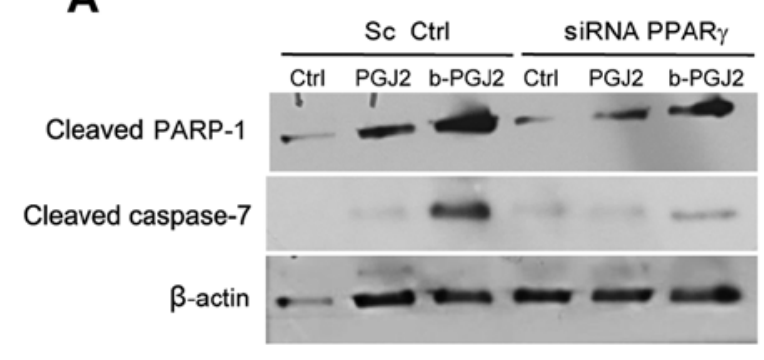

B

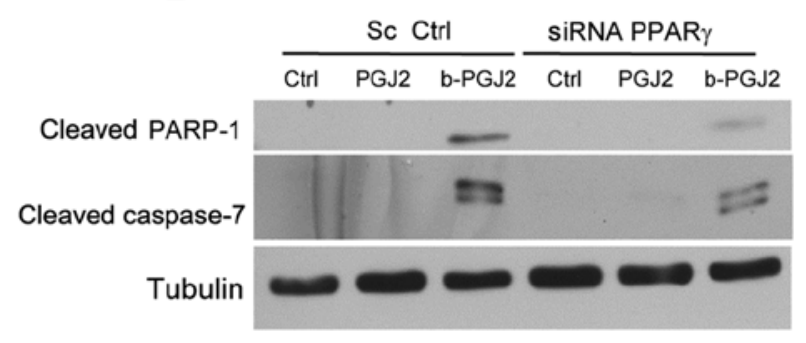

Cleaved PARP-1

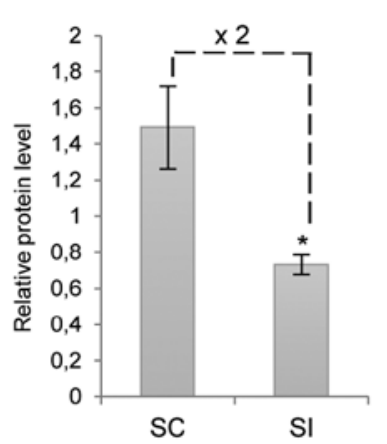

Cleaved caspase-7

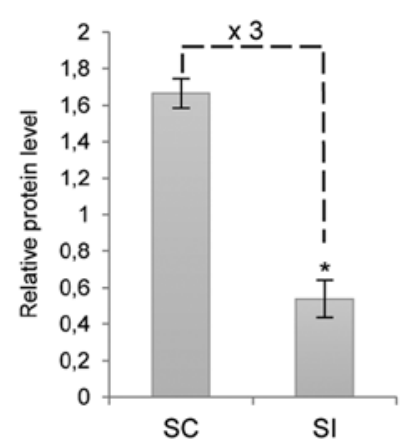

Cleaved PARP-1

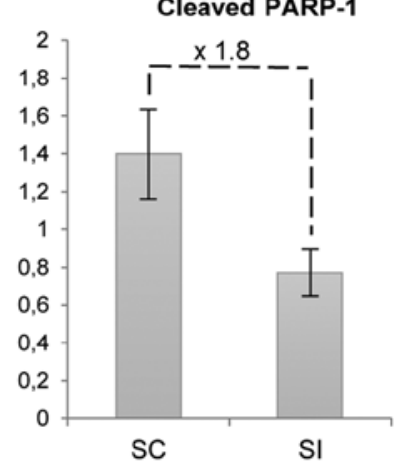

Cleaved caspase-7

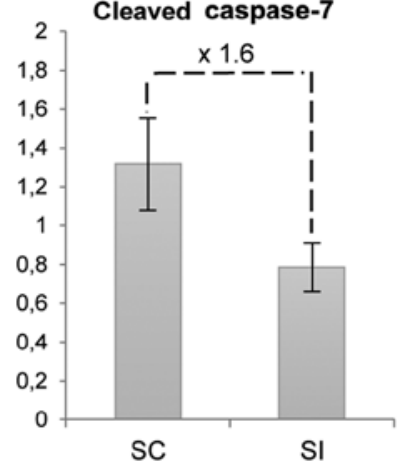

Figure 7. PPAR $\gamma$-dependent pathway is involved in b-15d-PGJ2-induced apoptosis. (A) MCF-7 and (B) MDA-MB-231 cells were transiently transfected with PPAR $\gamma$ siRNA (siRNA PPAR $\gamma$ ) or a scrambled siRNA (Sc Ctrl) and treated with $10 \mu \mathrm{M}$ b-15d-PGJ2 (b-PGJ2), $10 \mu \mathrm{M} 15 \mathrm{~d}-\mathrm{PGJ} 2$ (PGJ2) or 0.1\% ethanol (Ctrl). Following $24 \mathrm{~h}$ of treatment, the cells were lysed and subjected to western blot analyses with antibodies raised against cleaved PARP-1 and cleaved caspase-7. Tubulin and $\beta$-actin were used as loading controls. The histograms correspond to the quantification of the b-15d-PGJ2 treatment in scrambled siRNA (SC)- and PPAR $\gamma$ siRNA (SI)-transfected cells. Relative protein level corresponds to band intensity value for cleaved PARP-1 and cleaved caspase-7 adjusted to $\beta$-actin or tubulin for the MCF-7 and MDA-MB-231 cells, respectively. The values represent the means \pm SEM of 3 different experiments.

The aim of the present study was to determine whether the biotinylation of the natural PPAR $\gamma$ agonist, 15d-PGJ2, could further enhance its activity on breast cancer cells.

In this context, we examined the effects of b-15d-PGJ 2 on two breast cancer cell lines: MCF-7 (estrogen-dependent) and MDA-MB-231 (triple-negative) cells. According to previous studies, 15d-PGJ2 inhibited the proliferation of various cell lines with an $\mathrm{IC}_{50}$ value $>50 \mu \mathrm{M}(20,50)$. By contrast, the linkage of a biotin group to the terminal carboxylic acid of $15 d-P G J 2$ greatly enhanced its anti-proliferative effects on both cell lines. b-15d-PGJ2 significantly reduced MCF-7 cell viability with an $\mathrm{IC}_{50}$ value of $9.8 \pm 1.2 \mu \mathrm{M}$. b-15d-PGJ2 appeared more potent on the MDA-MB-231 cells, with an $\mathrm{IC}_{50}$ value of $6.0 \pm 0.1 \mu \mathrm{M}$. No viable cells remained in the presence of b-15d-PGJ2 $(10 \mu \mathrm{M})$, whereas $80 \%$ of the cells were viable in presence of $15 \mathrm{~d}-\mathrm{PGJ} 2(10 \mu \mathrm{M})$. In previous studies, we observed that the MDA-MB-231 cells were more sensitive than the MCF-7 cells to the biotinylated derivatives of TGZ $(35,36)$. Of note, the b-15d-PGJ2 inhibition efficiency was significantly higher than that of efatutazone, a recent PPAR $\gamma$ agonist undergoing clinical investigation, and whose activity has been demonstrated in vitro and in xenograft models $(51,52)$. Moreover, it has been described that PPAR $\gamma$ ligands and 15d-PGJ2 induce apoptosis $(53,54)$. In the present study, we observed strong apoptotic signals in response to a $24 \mathrm{~h}$ treatment with b-15d-PGJ2 $(10 \mu \mathrm{M})$, while no signal was detectable in response to treatment with $15 \mathrm{~d}-\mathrm{PGJ} 2(10 \mu \mathrm{M})$ in both cell lines.
Subsequenlty, we investigated the cause of this improved efficiency. One might suggest that biotin can improve the cellular intake of $\mathrm{b}-15 \mathrm{~d}-\mathrm{PGJ} 2$ through receptor-mediated internalization $(31-34,55)$. Biotin competition experiments were performed to test this hypothesis. However, the presence of free biotin did not decrease the anti-proliferative activity. We also investigated whether biotin could improve the general cellular uptake. To shed light into this matter, we performed cooperation experiments between biotin and 15d-PGJ2. In the MCF-7 and MDA-MB-231 cells, no significant differences were observed in the anti-proliferative effects of $15 \mathrm{~d}-\mathrm{PGJ} 2$ in presence of 5 or $10 \mu \mathrm{M}$ of biotin (data not shown). Thus, the improved activity was not the result of an increased uptake of the molecule mediated by the biotin group. Most likely, the structural modification of 15d-PGJ2 elicited a better activity of the biotinylated compound as we observed previously using biotinylated derivatives of TGZ $(35,36)$. One might suggest that biotinylation could alter the lipophilicity of 15d-PGJ2 and increase its entry into the cell. We then calculated the $\log \mathrm{P}$ of both molecules. The introduction of the biotin group induces a slight decrease of the $\mathrm{C} \log \mathrm{P}$ of 0.21 , which is not so significant. However, the non-biotinylated molecule bears a carboxylic acid group, which is ionized at the $\mathrm{pH}$ of the culture medium. This may lead to a lower diffusion of $15 \mathrm{~d}-\mathrm{PGJ} 2$ through the cellular membrane, and could explain a lower activity than the biotinylated compound.

Subsequently, we determined whether biotin could modify the 15d-PGJ2 PPAR $\gamma$ agonist activity. Co-transfection 
experiments demonstrated a clear improvement of PPAR $\gamma$ stimulation. Indeed, b-15d-PGJ2 induced a 5.5-fold stimulation compared to the solvent control. This activation was not statistically different from those induced by efatutazone. Moreover, in this condition, both ligands were significantly more efficient than 15d-PGJ2.

The question of whether the biotinylation of 15dPGJ2 could improve its binding to PPAR $\gamma$ still remained unanswered. Thus, to assess this question, we performed a docking analysis of b-15d-PGJ2 into PPAR $\gamma$. It appeared that b-15d-PGJ2 potentially docked into the LBD of PPAR $\gamma$ in a very similar manner as 15d-PGJ2. However, there were two differences: i) the distance between Cys285 of the receptor and C-13 of the prostaglandin derivative is shorter $(3.1 \AA$ ) in the case of the biotinylated derivative than for the non-biotinylated molecule $(3.8 \AA)$. Since this distance may affect the formation of a beneficial covalent bond between the two species, this could lead to a different transactivation ability of both molecules; ii) in the case of b-15d-PGJ2, a new H-bond interaction was seen with the receptor, compared to 15d-PGJ2. This interaction is related to the amide bond between $15 \mathrm{~d}-\mathrm{PGJ} 2$ and the 1,5-diaminopentane linker used for the biotinylation. Indeed, it may establish a hydrogen bond with Ser 342 and this could also lead to a different transactivation ability of both molecules. As a perspective, these two issues could be addressed as follows. First, as previously reported by Schopfer et al (56), a covalent binding of b-15d-PGJ2 to PPAR $\gamma$ LBD could be checked by means of HPLC-MS/MS after incubation. If this linkage was confirmed, a co-crystallization experiment could permit X-ray diffraction analysis, enabling the study of tight interactions between both partners. Second, a new and non-commercial analog of b-15d-PGJ2 could be chemically synthetized, with a structure which would not permit the hydrogen bond with Ser342. For example, this could be obtained by replacing both amide bonds of the linker by ester bonds. If this interaction was significant, such a new compound should be less active.

It may also be interesting to investigate whether the presence of b-15d-PGJ2 may improve interaction with co-activators or allow recruitment of additional activators. Moreover, we questioned the exact role played by PPAR $\gamma$ in the pro-apoptotic activity of b-15d-PGJ2. We observed a PPAR $\gamma$-dependent effect, since the pro-apoptotic response was significantly reduced following PPAR $\gamma$ silencing in MCF-7 cells. Despite the similar tendency, this decrease was not significant in the MDA-MB-231 cells, suggesting the possibility of a different mechanism of action. PPAR $\gamma$-independent mechanisms are probably also involved, as illustrated in other cell lines for 15d-PGJ2. For instance, as previously demonstrated, 15d-PGJ2 induced apoptosis through both PPAR $\gamma$-dependent and PPAR $\gamma$ independent pathways in Jurkat $\mathrm{T}$ lymphocytes, in spite of a specific role of PPAR $\gamma$ in cell death (57). The level of these two pathways may differ between the MCF-7 and MDA-MB-231 cells. Nevertheless, both pathways can result from the covalent binding of 15d-PGJ2 by Michael's addition to nucleophilic components targeting proteins of intracellular signaling pathways $(17,20,58)$ or the PPAR $\gamma$ LBD $(59,60)$. In conclusion, the biotinylation of 15d-PGJ2 markedly enhanced the anti-proliferative and pro-apoptotic activities in breast cancer cells, with a higher efficiency toward the triple-negative MDA-MB-231 cells compared to the estrogen-sensitive MCF-7 cells.
The present study contributes to the understanding of the mechanisms of action of b-15d-PGJ2 and suggests that its biotinylation may be a promising tool for the further development of novel therapeutic agents for triple-negative breast cancer. As a perspective, this study could be extended by in vivo experiments using mouse tumor xenografts derived from breast cancer cells. A number of studies have demonstrated the in vivo therapeutic effects of 15d-PGJ2 in inflammatory diseases, as well as in cancer $(26,27,61)$; however, no in vivo data obtained with b-15d-PGJ2 are available to date, at least to the best of our knowledge. Nevertheless, the in vivo administration of other biotinylated compounds has already been described. For instance, biotinylated nanoparticles containing doxorubicin appeared safer than doxorubicin solution in terms of cardio-compatibility and overall effect on morphology of vital organs (62). Besides, when administrated once weekly to patients with deep veinous thrombosis, idrabiotaparinux, the biotinylated form of the anticoagulant idraparinux, appeared to be at least as effective and safe as idraparinux during the 6-month treatment period (63). These data may encourage the commencement of in vivo studies with b-15d-PGJ2. The future of this compound will depend on the demonstration of its safety and efficacy.

\section{Acknowledgements}

The authors would like to thank Mrs. Marine Geoffroy for statistical analyses. The pPPRE $\mathrm{P}_{3}$-tk-luc, the human PPAR $\gamma$ expression vector and the pCMV- $\beta$-galactosidase $(\beta-\mathrm{Gal})$ construct were a generous gift from Professor Philippe Becuwe, Dr Lionel Domenjoud and Professor Oliver Nusse, respectively.

\section{Funding}

This study was supported by grants from the 'Ligue Contre le Cancer', the 'Conseil régional de Lorraine' the Université de Lorraine and CNRS. Christelle Colin was recipient of a $\mathrm{PhD}$ fellowship from the 'Ministère de l'enseignement supérieur et de la recherche'. Claudia Cerella was supported by a Waxweiler grant for cancer prevention research from the Action Lions 'Vaincre le Cancer'. Research at LBMCC is financially supported by the Fondation de Recherche Cancer et Sang, the Recherches Scientifiques Luxembourg Association, the Een Haerz fir kriibskrank Kanner Association, the Action Lions Vaincre le Cancer Association and the Télévie Luxembourg. MD was supported by the National Research Foundation (NRF), by the MEST of Korea for Tumor Microenvironment Global Core Research Center (GCRC) grant (grant number 2011-0030001), by the Seoul National University Research grant.

\section{Availability of data and materials}

The analyzed datasets generated during the study are available from the corresponding author on reasonable request.

\section{Authors' contributions}

CCo provided substantial contributions to the design of the study and acquisition, analysis, and interpretation of data for the study, and also revised the draft critically for important 
intellectual content. MM and AK provided substantial contributions to data acquisition and interpretation of the data, and also revised the draft critically for important intellectual content. CCe, MD, SF, MB and GM provided substantial contributions to the design of the study and interpretation of the data, and also revised the draft critically for important intellectual content. IGV and SK provided substantial contributions to the conception and design of the study and the acquisition of data, and also drafted the manuscript. All authors gave final approval of the version be published, and agree to be accountable for all aspects of the study in ensuring that questions related to the accuracy or integrity of any part of the study are appropriately investigated and resolved.

\section{Ethics approval and consent to participate}

Not applicable.

\section{Consent for publication}

Not applicable.

\section{Competing interests}

The authors declare that they have no competing interests.

\section{Referevnces}

1. Ferlay J, Soerjomataram I, Dikshit R, Eser S, Mathers C, Rebelo M, Parkin DM, Forman D and Bray F: Cancer incidence and mortality worldwide: Sources, methods and major patterns in GLOBOCAN 2012. Int J Cancer 136: E359-E386, 2015.

2. Early Breast Cancer Trialists' Collaborative Group (EBCTCG): Effects of chemotherapy and hormonal therapy for early breast cancer on recurrence and 15-year survival: An overview of the randomised trials. Lancet 365: 1687-1717, 2005.

3. Nahta R and Esteva FJ: HER2 therapy: Molecular mechanisms of trastuzumab resistance. Breast Cancer Res 8: 215, 2006.

4. Diers AR, Dranka BP, Ricart KC, Oh JY, Johnson MS, Zhou F, Pallero MA, Bodenstine TM, Murphy-Ullrich JE, Welch DR, et al: Modulation of mammary cancer cell migration by 15-deoxy-delta(12,14)-prostaglandin $\mathrm{J}(2)$ : Implications for antimetastatic therapy. Biochem J 430: 69-78, 2010.

5. Chen YC, Shen SC and Tsai SH: Prostaglandin D(2) and J(2) induce apoptosis in human leukemia cells via activation of the caspase 3 cascade and production of reactive oxygen species. Biochim Biophys Acta 1743: 291-304, 2005.

6. Kaikkonen S, Paakinaho V, Sutinen P, Levonen AL and Palvimo JJ: Prostaglandin 15d-PGJ(2) inhibits androgen receptor signaling in prostate cancer cells. Mol Endocrinol 27: 212-223, 2013.

7. Kim KR, Kim HJ, Lee SK, Ma GT, Park KK and Chung WY: 15-deoxy- $\Delta^{12,14}$-prostaglandin J2 inhibits osteolytic breast cancer bone metastasis and estrogen deficiency-induced bone loss. PLoS One 10: e0122764, 2015.

8. Trindade-da-Silva CA, Reis CF, Vecchi L, Napimoga MH, Sperandio M, Matias Colombo BF, Alves PT, Ward LS, Ueira-Vieira $C$ and Goulart LR: 15 -Deoxy- $\Delta(12,14)$-prostaglandin $\mathrm{J} 2$ induces apoptosis and upregulates SOCS3 in human thyroid cancer cells. PPAR Res 2016: 4106297, 2016.

9. Wu YC, Jhao YT, Cheng YC and Chen Y: 15-Deoxy- $\Delta^{12,14}$ prostaglandin J2inhibits migration of human thyroid carcinoma cells by disrupting focal adhesion complex and adherens junction. Oncol Lett 13: 2569-2576, 2017.

10. Yaacob NS, Nasir R and Norazmi MN: Influence of $17 \beta$-estradiol on 15 -deoxy- $\Delta^{12,14}$ prostaglandin J2 -induced apoptosis in MCF-7 and MDA-MB-231 cells. Asian Pac J Cancer Prev 14: 6761-6767, 2013.

11. Muhammad SN, Mokhtar NF and Yaacob NS: 15d-PGJ2 induces apoptosis of MCF-7 and MDA-MB-231 cells via increased intracellular calcium and activation of caspases, independent of ER $\alpha$ and ER $\beta$. Asian Pac J Cancer Prev 17: 3223-3228, 2016.
12. Forman BM, Tontonoz P, Chen J, Brun RP, Spiegelman BM and Evans RM: 15-Deoxy-delta 12, 14-prostaglandin J2 is a ligand for the adipocyte determination factor PPAR gamma. Cell 83: 803-812, 1995.

13. Kliewer SA, Lenhard JM, Willson TM, Patel I, Morris DC and Lehmann JM: A prostaglandin $\mathrm{J} 2$ metabolite binds peroxisome proliferator-activated receptor gamma and promotes adipocyte differentiation. Cell 83: 813-819, 1995.

14. Issemann I and Green S: Activation of a member of the steroid hormone receptor superfamily by peroxisome proliferators. Nature 347: 645-650, 1990.

15. Mangelsdorf DJ and Evans RM: The RXR heterodimers and orphan receptors. Cell 83: 841-850, 1995.

16. Yang W, Rachez C and Freedman LP: Discrete roles for peroxisome proliferator-activated receptor gamma and retinoid $\mathrm{X}$ receptor in recruiting nuclear receptor coactivators. Mol Cell Biol 20: 8008-8017, 2000

17. Kim HJ, Kim JY, Meng Z, Wang LH, Liu F, Conrads TP, Burke TR, Veenstra TD and Farrar WL: 15-deoxy-Delta ${ }^{12,14}$ prostaglandin $\mathrm{J} 2$ inhibits transcriptional activity of estrogen receptor-alpha via covalent modification of DNA-binding domain. Cancer Res 67: 2595-2602, 2007.

18. Wang JJ and Mak OT: Induction of apoptosis by $15 d-P G J 2$ via ROS formation: An alternative pathway without PPAR $\gamma$ activation in non-small cell lung carcinoma A549 cells. Prostaglandins Other Lipid Mediat 94: 104-111, 2011.

19. Kar R, Singha PK, Venkatachalam MA and Saikumar P: A novel role for MAP1 LC3 in nonautophagic cytoplasmic vacuolation death of cancer cells. Oncogene 28: 2556-2568, 2009.

20. Lecomte J, Flament S, Salamone S, Boisbrun M, Mazerbourg S, Chapleur Y and Grillier-Vuissoz I: Disruption of ERalpha signalling pathway by PPARgamma agonists: Evidences of PPARgammaindependent events in two hormone-dependent breast cancer cell lines. Breast Cancer Res Treat 112: 437-451, 2008.

21. Qin C, Burghardt R, Smith R, Wormke M, Stewart J and Safe S: Peroxisome proliferator-activated receptor gamma agonists induce proteasome-dependent degradation of cyclin D1 and estrogen receptor alpha in MCF-7 breast cancer cells. Cancer Res 63: $958-964,2003$

22. Uchida K and Shibata T: 15 -Deoxy-Delta(12,14)-prostaglandin J2: An electrophilic trigger of cellular responses. Chem Res Toxicol 21: 138-144, 2008

23. Malaviya A and Sylvester PW: Synergistic antiproliferative effects of combined $\gamma$-tocotrienol and PPAR $\gamma$ antagonist treatment are mediated through PPAR $\gamma$-independent mechanisms in breast cancer cells. PPAR Res 2014: 439146, 2014.

24. de Jong E, Winkel P, Poelstra K and Prakash J: Anticancer effects of 15d-prostaglandin-J2 in wild-type and doxorubicin-resistant ovarian cancer cells: Novel actions on SIRT1 and HDAC. PLoS One 6: e25192, 2011.

25. Koyama M, Izutani Y, Goda AE, Matsui TA, Horinaka M, Tomosugi M, Fujiwara J, Nakamura Y, Wakada M, Yogosawa S, et al: Histone deacetylase inhibitors and 15-deoxy-Delta ${ }^{12,14}$ prostaglandin $\mathrm{J} 2$ synergistically induce apoptosis. Clin Cancer Res 16: 2320-2332, 2010 .

26. Shin SW, Seo CY, Han H, Han JY, Jeong JS, Kwak JY and Park JI: 15d-PGJ2 induces apoptosis by reactive oxygen speciesmediated inactivation of Akt in leukemia and colorectal cancer cells and shows in vivo antitumor activity. Clin Cancer Res 15: 5414-5425, 2009

27. Prakash J,BansalR,PostE, de Jager-Krikken A,Lub-de Hooge MN and Poelstra K: Albumin-binding and tumor vasculature determine the antitumor effect of 15-deoxy-Delta-(12,14)-prostaglandin-J(2) in vivo. Neoplasia 11: 1348-1358, 2009.

28. Prost S, Relouzat F, Spentchian M, Ouzegdouh Y, Saliba J, Massonnet G, Beressi JP, Verhoeyen E, Raggueneau V, Maneglier B, et al: Erosion of the chronic myeloid leukaemia stem cell pool by PPAR $\gamma$ agonists. Nature 525: 380-383, 2015.

29. Komatsu Y, Yoshino T, Yamazaki K, Yuki S, Machida N, Sasaki T, Hyodo I, Yachi Y, Onuma H and Ohtsu A: Phase 1 study of efatutazone, a novel oral peroxisome proliferator-activated receptor gamma agonist, in combination with FOLFIRI as second-line therapy in patients with metastatic colorectal cancer. Invest New Drugs 32: 473-480, 2014.

30. Murakami H, Ono A, Takahashi T, Onozawa Y, Tsushima T, Yamazaki K, Jikoh T, Boku N and Yamamoto N: Phase I study of Efatutazone, an oral PPAR $\gamma$ agonist, in patients with metastatic solid tumors. Anticancer Res 34: 5133-5141, 2014.

31. Russell-Jones G, McTavish K, McEwan J, Rice J and Nowotnik D: Vitamin-mediated targeting as a potential mechanism to increase drug uptake by tumours. J Inorg Biochem 98: 1625-1633, 2004. 
32. Shi JF, Wu P, Jiang ZH and Wei XY: Synthesis and tumor cell growth inhibitory activity of biotinylated annonaceous acetogenins. Eur J Med Chem 71: 219-228, 2014.

33. Taheri A,Dinarvand R,AtyabiF,NouriF,AhadiF, Ghahremani MH, Ostad SN, Borougeni AT and Mansoori P: Targeted delivery of methotrexate to tumor cells using biotin functionalized methotrexate-human serum albumin conjugated nanoparticles. J Biomed Nanotechnol 7: 743-753, 2011.

34. Yang W, Cheng Y, Xu T, Wang X and Wen LP: Targeting cancer cells with biotin-dendrimer conjugates. Eur J Med Chem 44 862-868, 2009

35. Colin C, Salamone S, Grillier-Vuissoz I, Boisbrun M, Kuntz S, Lecomte J, Chapleur Y and Flament S: New troglitazone derivatives devoid of PPAR $\gamma$ agonist activity display an increased antiproliferative effect in both hormone-dependent and hormoneindependent breast cancer cell lines. Breast Cancer Res Treat 124: 101-110, 2010.

36. Salamone S, Colin C, Grillier-Vuissoz I, Kuntz S, Mazerbourg S, Flament S, Martin H, Richert L, Chapleur Y and Boisbrun M: Synthesis of new troglitazone derivatives: Anti-proliferative activity in breast cancer cell lines and preliminary toxicological study. Eur J Med Chem 51: 206-215, 2012.

37. Pishvaian MJ, Marshall JL, Wagner AJ, Hwang JJ, Malik S, Cotarla I, Deeken JF, He AR, Daniel H, Halim AB, et al: A phase 1 study of efatutazone, an oral peroxisome proliferatoractivated receptor gamma agonist, administered to patients with advanced malignancies. Cancer 118: 5403-5413, 2012.

38. Colin-Cassin C, Yao X, Cerella C, Chbicheb S, Kuntz S, Mazerbourg S, Boisbrun M, Chapleur Y, Diederich M, Flament S, et al: PPAR $\gamma$-inactive $\Delta 2$-troglitazone independently triggers ER stress and apoptosis in breast cancer cells. Mol Carcinog 54: 393-404, 2015

39. Morris GM, Huey R, Lindstrom W, Sanner MF, Belew RK, Goodsell DS and Olson AJ: AutoDock4 and AutoDockTools4: Automated docking with selective receptor flexibility. J Comput Chem 30: 2785-2791, 2009.

40. Furukawa A, Arita T, Fukuzaki T, Satoh S, Mori M, Honda T, Matsui Y, Wakabayashi K, Hayashi S, Araki K, et al: Substituents at the naphthalene $\mathrm{C} 3$ position of (-)-Cercosporamide derivatives significantly affect the maximal efficacy as PPAR $\gamma$ partial agonists. Bioorg Med Chem Lett 22: 1348-1351, 2012.

41. Waku T, Shiraki T, Oyama T, Fujimoto Y, Maebara K, Kamiya N, Jingami $\mathrm{H}$ and Morikawa K: Structural insight into PPARgamma activation through covalent modification with endogenous fatty acids. J Mol Biol 385: 188-199, 2009.

42. Dennington R, Keith TA and Millam JM: GaussView, version 5.0. Semichem, Inc., Shawnee Mission, KS, 2008.

43. Stewart JJ: Optimization of parameters for semiempirical methods V: Modification of NDDO approximations and application to 70 elements. J Mol Model 13: 1173-1213, 2007

44. Frisch MJ, Trucks GW, Schlegel HB, Scuseria GE, Robb MA, Cheeseman JR, Scalmani G, Barone V, Mennucci B Petersson GA, et al: Gaussian 09, revision D.01. Gaussian, Inc., Wallingford, CT, 2013.

45. Jakalian A, Jack DB and Bayly CI: Fast, efficient generation of high-quality atomic charges. AM1-BCC model: II.Parameterization and validation. J Comput Chem 23: 1623-1641, 2002.

46. Case DA, Berryman JT, Betz RM, Cerutti DS, Cheatham III TE, Darden TA, Duke RE, Giese TJ, Gohlke H, Goetz AW, et al: AMBER 2015. University of California, San Francisco, CA, 2015.

47. Maier JA, Martinez C, Kasavajhala K, Wickstrom L, Hauser KE and Simmerling C: ff14SB: Improving the accuracy of protein side chain and backbone parameters from ff99SB. J Chem Theory Comput 11: 3696-3713, 2015.
48. Qiao L, Dai Y, Gu Q, Chan KW, Ma J, Lan HY, Zou B, Rocken C, Ebert MP and Wong BC: Loss of XIAP sensitizes colon cancer cells to PPARgamma independent antitumor effects of troglitazone and 15-PGJ2. Cancer Lett 268: 260-271, 2008.

49. Ray DM, Akbiyik F and Phipps RP: The peroxisome proliferator-activated receptor gamma (PPARgamma) ligands 15-deoxy-Delta ${ }^{12,14}$-prostaglandin $\mathrm{J} 2$ and ciglitazone induce human B lymphocyte and B cell lymphoma apoptosis by PPARgamma-independent mechanisms. J Immunol 177: 5068-5076, 2006.

50. Shen D, Deng C and Zhang M: Peroxisome proliferator-activated receptor gamma agonists inhibit the proliferation and invasion of human colon cancer cells. Postgrad Med J 83: 414-419, 2007.

51. Pirat C, Farce A, Lebègue N, Renault N, Furman C, Millet R, Yous S, Speca S, Berthelot P, Desreumaux P, et al: Targeting peroxisome proliferator-activated receptors (PPARs): Development of modulators. J Med Chem 55: 4027-4061, 2012.

52. Shimazaki N, Togashi N, Hanai M, Isoyama T, Wada K, Fujita T, Fujiwara K and Kurakata S: Anti-tumour activity of CS-7017, a selective peroxisome proliferator-activated receptor gamma agonist of thiazolidinedione class, in human tumour xenografts and a syngeneic tumour implant model. Eur J Cancer 44: 1734-1743, 2008

53. Ishihara S, Rumi MA, Okuyama T and Kinoshita Y: Effect of prostaglandins on the regulation of tumor growth. Curr Med Chem Anticancer Agents 4: 379-387, 2004.

54. Zhang Z, Xu Y, Xu Q and Hou Y: PPAR $\gamma$ against tumors by different signaling pathways. Onkologie 36: 598-601, 2013.

55. Kansara V, Luo S, Balasubrahmanyam B, Pal D and Mitra AK Biotin uptake and cellular translocation in human derived retinoblastoma cell line (Y-79): A role of hSMVT system. Int J Pharm 312: 43-52, 2006.

56. Schopfer FJ, Cole MP, Groeger AL, Chen CS, Khoo NK, Woodcock SR, Golin-Bisello F, Motanya UN, Li Y, Zhang J, et al: Covalent peroxisome proliferator-activated receptor gamma adduction by nitro-fatty acids: Selective ligand activity and antidiabetic signaling actions. J Biol Chem 285: 12321-12333, 2010.

57. Ferreira-Silva V, Rodrigues AC, Hirata TD, Hirabara SM and Curi R: Effects of 15-deoxy-Delta12, 14 prostaglandin J2 and ciglitazone on human cancer cell cycle progression and death: The role of PPARgamma. Eur J Pharmacol 580: 80-86, 2008.

58. Marcone S and Fitzgerald DJ: Proteomic identification of the candidate target proteins of 15 -deoxy-delta ${ }^{12,14}$-prostaglandin $\mathrm{J} 2$. Proteomics 13: 2135-2139, 2013.

59. Itoh T, Fairall L, Amin K, Inaba Y, Szanto A, Balint BL, Nagy L, Yamamoto K and Schwabe JW: Structural basis for the activation of PPARgamma by oxidized fatty acids. Nat Struct Mol Biol 15: 924-931, 2008

60. Shiraki T, Kamiya N, Shiki S, Kodama TS, Kakizuka A and Jingami H: Alpha,beta-unsaturated ketone is a core moiety of natural ligands for covalent binding to peroxisome proliferatoractivated receptor gamma. J Biol Chem 280: 14145-14153, 2005.

61. Surh YJ, Na HK, Park JM, Lee HN, Kim W, Yoon IS and Kim DD: 15 -Deoxy- $\Delta^{12},{ }^{14}$-prostaglandin $\mathrm{J}_{2}$, an electrophilic lipid mediator of anti-inflammatory and pro-resolving signaling. Biochem Pharmacol 82: 1335-1351, 2011.

62. Singh Y, Durga Rao Viswanadham KK, Kumar Jajoriya A, Meher JG, Raval K, Jaiswal S, Dewangan J, Bora HK, Rath SK, Lal J, et al: Click biotinylation of PLGA template for biotin receptor oriented delivery of doxorubicin hydrochloride in 4T1 cell-induced breast cancer. Mol Pharm 14: 2749-2765, 2017.

63. Equinox Investigators: Efficacy and safety of once weekly subcutaneous idrabiotaparinux in the treatment of patients with symptomatic deep venous thrombosis. J Thromb Haemost 9: 92-99, 2011. 